\title{
Assessment of Intraspecific Variation in Clavispora sp. by Restriction Mapping of Tandemly Repeated Deoxyribonucleic Acid
}

\author{
MARC-ANDRE LACHANCE,* ALEXANDER LUTTIKHUIS, LAURA L. ANWEILER, DASCHA L. PAYLOR, AND \\ LORRAINE G. OLSON \\ Department of Plant Sciences, University of Western Ontario, London, Ontario, Canada N6A $5 B 7$
}

\begin{abstract}
The total deoxyribonucleic acids from 10 strains of an undescribed cactophilic species of Clavispora were subjected to restriction analyses with endonucleases $A p a I$, EcoRI, KpnI, and XhoI. A 7.6-kilobase tandemly repeated segment of the genome was mapped and found to possess both conserved regions and variable regions among the strains examined. A total of eight possible endonuclease recognition sites were identified. Two strains were heterogeneous, and one of these shared one of its restriction maps with three other strains. In one instance, variation was correlated with a habitat difference. In addition, all strains possessed very large (up to 28-kilobase) repetitive EcoRI fragments. Preliminary results indicate that this yeast species shares parts of its conserved region with Clavispora lusitaniae, but that there are major differences between the two species in their variable regions. The use of restriction mapping in taxonomic and other investigations of yeasts is discussed.
\end{abstract}

The investigation of nucleic acids is continuing to have a major impact on yeast taxonomy $(4,7)$. The two major approaches used are the determination of guanine-pluscytosine contents and the determination of relative percentages of in vitro deoxyribonucleic acid (DNA)-DNA reassociation. DNA nucleotide composition has the advantage that only one value is required for each strain studied, but the taxonomic intrepretation of the data obtained is ambiguous. Strains which differ in base composition by more than approximately 1.0 to $1.5 \%$ (as determined by buoyant density) are considered genetically unrelated (4), but strains with nearly identical values may or may not be related. DNA-DNA reassociation yields a much less equivocal measure of the base sequence similarity between two individuals. This method has been used for determinations of conspecificity (generally associated with relative values of approximately $70 \%$ or more) and for assessment of genetic divergence among varieties of the same species and among closely related species (lower reassociation values). Reassociation between DNA and ribosomal ribonucleic acid ( $\mathrm{RNA}$ ) is known to provide information about more distantly related yeast taxa (1). The evolutionary rate of rRNA is such that intergeneric comparisons are possible. Yeast taxonomists have tended to avoid ribonucleic acid for such studies, possibly due to the technical difficulties associated with its purification and preservation.

Reassociation methods in general suffer from one common disadvantage. They require pairwise determinations, with the result that to circumscribe genetic relatedness fully among $n$ moderately or distantly related strains, $n(n-1) / 2$ experiments are required. A more convenient approach to yeast molecular taxonomy would be one in which each strain requires a single set of experimental treatments. This approach should be directed toward intrinsic features endowed with both low and high evolutionary rates in order to allow comparisons among both close and distant relatives. The costs incurred by the methodology should be low enough to allow its application to large numbers of strains. In concrete terms, there would be much taxonomic interest in a method which would provide, for each individual, a unique set of

\footnotetext{
* Corresponding author.
}

information about selected DNA sequences and which would make use of the extensive technology presently available to study DNA.

One early step in the preparation of yeast DNA for taxonomic investigations has been the elimination of repeated sequences (4). Therefore, the taxonomic significance of such sequences is unknown. In this paper, we describe the application of restriction mapping of repetitive DNA to interfertile strains of a cactophilic species of Clavispora collected in a number of geographically distinct localities. As a first step in assessing the taxonomic usefulness of this approach, intraspecific variation was explored, and the

TABLE 1. Clavispora sp. strains used in this study

\begin{tabular}{|c|c|c|c|c|}
\hline $\begin{array}{c}\text { UWO(PS) } \\
\text { no. }{ }^{a}\end{array}$ & $\begin{array}{l}\text { Mating } \\
\text { type }^{b}\end{array}$ & $\begin{array}{l}\text { Isolation } \\
\text { substrate }\end{array}$ & $\begin{array}{l}\text { Source of } \\
\text { isolation } \\
\text { substrate }\end{array}$ & Locality \\
\hline $83-718-1$ & $\mathrm{~h}_{1}$ & Fruit & $\begin{array}{l}\text { Cephalocereus } \\
\text { royenii }\end{array}$ & $\begin{array}{l}\text { Little Conception } \\
\text { Island, } \\
\text { Bahamas }\end{array}$ \\
\hline $83-754-1$ & $\mathbf{h}_{1}$ & Fruit & $\begin{array}{r}\text { Opuntia } \\
\text { stricta }\end{array}$ & $\begin{array}{c}\text { Great Inagua, } \\
\text { Bahamas }\end{array}$ \\
\hline $83-793-1$ & $\mathrm{~h}_{1}$ & $\begin{array}{l}\text { Drosophila } \\
\text { muilleri }\end{array}$ & $\begin{array}{r}\text { Opuntia } \\
\text { stricta }\end{array}$ & $\begin{array}{c}\text { Great Inagua, } \\
\text { Bahamas }\end{array}$ \\
\hline $83-803-2$ & $\mathrm{~h}_{2}$ & $\begin{array}{l}\text { Drosophila } \\
\text { mulleri }\end{array}$ & $\begin{array}{r}\text { Opuntia } \\
\text { stricta }\end{array}$ & $\begin{array}{c}\text { Great Inagua, } \\
\text { Bahamas }\end{array}$ \\
\hline $83-814-2$ & $h_{1}$ & $\begin{array}{l}\text { Drosophila } \\
\text { mulleri }\end{array}$ & $\begin{array}{r}\text { Opuntia } \\
\text { stricta }\end{array}$ & $\begin{array}{c}\text { Great Inagua, } \\
\text { Băhamas }\end{array}$ \\
\hline $83-827-1$ & $h_{1}$ & $\begin{array}{l}\text { Drosophila } \\
\quad \text { mayaguana }\end{array}$ & $\begin{array}{l}\text { Opuntia } \\
\text { stricta }\end{array}$ & $\begin{array}{c}\text { Great Inagua, } \\
\text { Bahamas }\end{array}$ \\
\hline $83-877-1$ & $\mathbf{h}_{2}$ & Fruit & $\begin{array}{r}\text { Opuntia } \\
\text { stricta }\end{array}$ & Navassa Island \\
\hline 83-878-1 & $\mathrm{h}_{2}$ & Fruit & $\begin{array}{r}\text { Opuntia } \\
\text { stricta }\end{array}$ & Navassa Island \\
\hline $83-1030-1$ & $\mathrm{~h}_{1}$ & $\begin{array}{l}\text { Drosophila } \\
\text { mulleri }\end{array}$ & $\begin{array}{r}\text { Opuntia } \\
\text { stricta }\end{array}$ & Jamaica \\
\hline 83-1074-1 & $\mathrm{h}_{1}$ & Fruit & $\begin{array}{r}\text { Opuntia } \\
\text { stricta }\end{array}$ & Cayman Brac \\
\hline
\end{tabular}

${ }^{a}$ University of Western Ontario Department of Plant Sciences yeast culture collection.

${ }^{b}$ Mating types were arbitrarily designated $h_{1}$ [same as strain UWO(PS) 83-718-1] or $h_{2}$ (opposite mating type). 
TABLE 2. Small repetitive DNA restriction fragments identified in strains of Clavispora sp.

\begin{tabular}{|c|c|c|c|c|c|c|c|c|c|c|c|}
\hline \multicolumn{2}{|c|}{ Fragment } & \multicolumn{10}{|c|}{ Clavispora sp. strain: } \\
\hline $\begin{array}{l}\text { Size } \\
(\mathrm{kb})\end{array}$ & Type $^{a}$ & $\begin{array}{c}\text { UWO(PS) } \\
83-718-1\end{array}$ & $\begin{array}{l}\text { UWO(PS) } \\
83-803-2\end{array}$ & $\begin{array}{c}\text { UWO(PS) } \\
83-754-1\end{array}$ & $\begin{array}{c}\text { UWO(PS) } \\
83-793-1\end{array}$ & $\begin{array}{l}\text { UWO(PS) } \\
83-1030-1\end{array}$ & $\begin{array}{c}\text { UWO(PS) } \\
83-827-1\end{array}$ & $\begin{array}{l}\text { UWO(PS) } \\
83-877-1\end{array}$ & $\begin{array}{l}\text { UWO(PS) } \\
83-878-1\end{array}$ & $\begin{array}{l}\text { UWO(PS) } \\
83-814-2\end{array}$ & $\begin{array}{l}\text { UWO(PS) } \\
83-1074-1\end{array}$ \\
\hline $\begin{array}{l}7.6 \\
5.4\end{array}$ & $\begin{array}{l}X-A-E-X \\
A-E-X-A\end{array}$ & + & + & + & + & + & + & + & + & + & + \\
\hline 4.4 & $A--E--A$ & & + & + & + & + & & & & + & \\
\hline 4.2 & $\mathrm{E}--\mathrm{A}--\mathrm{E}$ & + & + & & & & & & & & \\
\hline 4.0 & $A--E--A$ & + & & & & & & & & & \\
\hline 3.5 & $\mathrm{AX}-\mathrm{E}-\mathrm{AX}$ & & & & & & & & & + & \\
\hline 3.4 & E-A-X-E & + & + & + & + & + & + & + & + & + & + \\
\hline 3.3 & $\mathrm{AE}--\mathrm{AE}$ & & + & & & & & & & & \\
\hline 3.3 & $A-E-X-A$ & + & + & + & + & + & + & + & + & + & + \\
\hline 3.0 & $E X---E X$ & + & + & & & & & & & & \\
\hline 3.0 & EX-A-EX & & & + & + & + & + & + & + & + & + \\
\hline 3.0 & $\mathrm{AE}---\mathrm{AE}$ & + & & & & & & & & & \\
\hline 2.5 & $E-----E$ & & & & & & & & & + & \\
\hline 2.5 & $\mathrm{E}--\mathrm{A}--\mathrm{E}$ & & & + & + & + & + & + & + & + & + \\
\hline 2.4 & $\mathrm{~A}--\mathrm{E}--\mathrm{A}$ & & & & & & & & & & + \\
\hline 2.3 & $A--E--A$ & & & & & & + & + & + & + & \\
\hline 2.2 & $\mathrm{~A}--\mathrm{E}--\mathrm{A}$ & & & & & & & & & & + \\
\hline 2.2 & $\mathrm{AE}-\mathrm{X}-\mathrm{AE}$ & + & + & + & + & + & + & + & + & + & + \\
\hline 2.0 & $A--E--A$ & & & & & & + & + & + & + & + \\
\hline 1.8 & $\mathrm{E}--\mathrm{A}--\mathrm{E}$ & & & & & & & & & & + \\
\hline 1.7 & $\mathrm{AX}---\mathrm{AX}$ & + & + & + & + & + & + & + & + & + & + \\
\hline 1.7 & $\mathrm{E}-----\mathrm{E}$ & & & + & + & + & & & & & \\
\hline 1.7 & $\mathrm{E}--\mathrm{A}--\mathrm{E}$ & & & & & & + & + & + & + & \\
\hline 1.6 & $E--A--E$ & & & & & & & & & & + \\
\hline 1.5 & AX-E-AX & + & + & + & + & t & + & + & + & + & + \\
\hline 1.3 & $\mathrm{AE}---\mathrm{AE}$ & & & + & + & t & + & + & + & + & + \\
\hline 1.2 & $\mathrm{AE}---\mathrm{AE}$ & & + & + & + & + & + & + & + & + & + \\
\hline 1.1 & $A E---A E$ & & & & & & & & & & + \\
\hline 1.0 & $\mathrm{AE}---\mathrm{AE}$ & + & + & + & + & + & + & + & + & + & + \\
\hline 0.8 & $\mathrm{AE}---\mathrm{AE}$ & + & & & & & & & & & \\
\hline 0.6 & $\mathrm{AE}---\mathrm{AE}$ & & & & & & + & + & + & + & + \\
\hline 0.4 & $E X---E X$ & + & + & + & + & + & + & + & + & + & + \\
\hline 0.4 & $\mathrm{~A}-----\mathrm{A}$ & + & & & & & & & & & \\
\hline
\end{tabular}

${ }^{a}$ See text for explanation.

extension of such studies to interspecific comparisons is discussed.

\section{MATERIALS AND METHODS}

Microorganisms. The 10 strains used in this study were recovered from cactus fruits and associated Drosophila spp. (H. J. Phaff, W. T. Starmer, and M. A. Lachance, unpublished data). The sources and mating types of these strains are shown in Table 1. They were identified as haploid heterothallic members of an undescribed species of the genus Clavispora which has been provisionally designated "Clavispora opuntiae" (H. J. Phaff and W. T. Starmer, personal communication). These organisms were maintained on YM agar (Difco Laboratories, Detroit, Mich.) slants.

DNA preparation. Each strain was grown in 1 liter of $0.5 \%$ yeast extract $-5 \%$ glucose broth at $25^{\circ} \mathrm{C}$ with shaking. The method of Cryer et al. (3) was used to extract and purify high molecular-weight DNA, with some modifications. Protoplasts were prepared from $10 \mathrm{~g}$ of fresh yeast cells with Zymolyase 60,000 (50 $\mu \mathrm{g} / \mathrm{ml}$; Miles Laboratories, Inc., Elkhart, Ind.) and were lysed in the presence of a nonspecific protease $(1 \mathrm{mg} / \mathrm{ml})$. Ribonucleic acid was eliminated with pancreatic ribonuclease $(60 \mu \mathrm{g} / \mathrm{ml})$. No steps were taken to eliminate polysaccharides enzymatically. The protease and ribonuclease used were obtained from Boehringer Mannheim Canada Ltd., Dorval, Quebec, Canada. DNA concentrations were measured by determining absorbance at
$260 \mathrm{~nm}$ with a model UV-250 spectrophotometer (Shimadzu, Kyoto, Japan). This apparatus was also used to obtain densitometric profiles of photographic negatives of restriction digests to estimate the proportion of repeated DNA.

Preparation of restriction fragments. Total yeast DNA (7 $\mu \mathrm{g})$ was treated with restriction endonucleases ApaI, EcoRI, $K p n I$, and $X h o I$ by using the recommendations of the manufacturer (Boehringer Mannheim). These enzymes were chosen for their highly specific recognition of hexameric sites (five or fewer cuts on phage $\lambda$ DNA) and for their relatively low cost. For double digestions, DNA was treated first with one enzyme, precipitated with 2 volumes of ethanol, and centrifuged at $15,000 \times g$ for $20 \mathrm{~min}$. The supernatant was discarded, and the pellet was dried and reconstituted in water. A second enzyme was then added. For triple digestions, the process was repeated once more with the third enzyme.

Agarose electrophoresis. Restriction fragments were concentrated under a vacuum and subjected to agarose electrophoresis as recommended by Maniatis et al. (5). After staining in ethidium bromide $(1 \mu \mathrm{g} / \mathrm{ml}$; Boehringer Mannheim) for $45 \mathrm{~min}$, the gels were photographed over a ultraviolet transilluminator (302 nm; Ultra-Violet Products, Inc., San Gabriel, Calif.).

Fragment characterization and nomenclature. Each agarose gel was internally calibrated with a HindIII digest of phage $\lambda$ (DNA molecular weight marker II; Boehringer Mannheim), and the size of each yeast DNA fragment was 
TABLE 3. Large repetitive DNA EcoRI fragments in strains of Clavispora sp.

\begin{tabular}{|c|c|c|c|c|c|c|c|c|c|c|}
\hline \multirow{2}{*}{$\begin{array}{l}\text { Fragment } \\
\text { size }(\mathrm{kb})\end{array}$} & \multicolumn{10}{|c|}{ Clavispora sp. strain: } \\
\hline & $\begin{array}{l}\text { UWO(PS) } \\
83-718-1\end{array}$ & $\begin{array}{c}\text { UWO(PS) } \\
83-754-1\end{array}$ & $\begin{array}{c}\text { UWO(PS) } \\
83-793-1\end{array}$ & $\begin{array}{l}\text { UWO(PS) } \\
83-1030-1\end{array}$ & $\begin{array}{c}\text { UWO(PS) } \\
83-803-2\end{array}$ & $\begin{array}{c}\text { UWO(PS) } \\
83-814-2\end{array}$ & $\begin{array}{l}\text { UWO(PS) } \\
83-827-1\end{array}$ & $\begin{array}{l}\text { UWO(PS) } \\
83-877-1\end{array}$ & $\begin{array}{l}\text { UWO(PS) } \\
83-878-1\end{array}$ & $\begin{array}{l}\text { UWO(PS) } \\
83-1074-1\end{array}$ \\
\hline 29 & + & & & & & & & & & \\
\hline 27 & & & & & + & + & + & + & + & + \\
\hline 24 & & & & + & & & & & & \\
\hline 15 & & + & + & & & & & & & \\
\hline 12 & & + & + & & & & & & & \\
\hline 8.8 & & & & + & & & & & & \\
\hline 8.6 & & + & + & & & & & & & \\
\hline
\end{tabular}

calculated with reference to a standard curve. The sizes of large (8-kilobase [kb] or more) fragments were determined on $0.5 \%$ agarose gels, and the smaller fragments were measured on $1.5 \%$ agarose gels. The nature of each fragment was deduced from the results of multiple digestions. For example, a fragment obtained after digestion with ApaI but not present after treatment with EcoRI or XhoI, was known to possess terminal $A p a \mathrm{I}$ (A) sites and intercalary EcoRI (E) and XhoI (X) sites; it was recorded as A-E-X-A. By contrast, an ApaI fragment which persisted when it was additionally digested with the other two enzymes was known to possess terminal ApaI recognition sequences but no intercalary sites; thus, it was recorded as $\mathrm{A}-\mathrm{A}$.

\section{RESULTS AND DISCUSSION}

Restriction patterns of repetitive DNA. The results for the Clavispora sp. strains examined in this study are shown in Tables 2 and 3. The recovery in all strains of the 7.6-kb XhoI, 3.4-kb EcoRI, and 3.3-kb ApaI fragments (Table 2) indicated that the terminal restriction sites of these fragments are located in the more conserved regions of the sequences in question. With the exception of the fragments from strains UWO(PS) 83-814-2 and UWO(PS) 83-1074-1, the sizes of all of the smaller repetitive DNA fragments obtained by single digestion with EcoRI or ApaI added up to approximately 7.6 kb. Examples of the patterns obtained are shown in Fig. 1. Equally interesting was the observation that among strains lacking a 4.4-kb ApaI fragment, all but strain UWO(PS) 83-718-1 possessed a number of smaller ApaI fragments whose sizes added up to a value near $4.4 \mathrm{~kb}$. The same phenomenon existed with respect to the 4.2-kb EcoRI fragment of strains UWO(PS) 83-718-1 and UWO(PS) 83-803-2. Digestion with KpnI (data not shown) did not result in the production of any intense fragments.

Variation among the smaller repeated fragments in Clavispora sp. strains. The restriction patterns in Table 2 were used to construct the maps shown in Fig. 2. The first $1.6-\mathrm{kb}$ region was identical in all maps, indicating the conserved nature of the sites. The failure to observe perfect additivity in strains UWO(PS) 83-814-2 and UWO(PS) 83-1074-1 was noted above and is explained by the heterogeneity in the tandem repeats of these strains.

The more variable region from $3.0 \mathrm{~kb}$ upward (Fig. 2) was characterized largely by the presence or absence of $A p a \mathrm{I}$ or EcoRI sites at certain defined positions rather than by the more or less random appearance and disappearance of restriction sites. This observation has interesting implications from a phylogenetic standpoint. The expected frequency of random appearance of any specific hexameric recognition site, such as an $A p a \mathrm{I}$ or EcoRI site, is very low $\left(4^{-6}\right)$. The appearance of such a site as a result of a single random mutation is also very unlikely. Even if five of the six bases in a sequence are already in place, the probability of obtaining that sequence from a single random mutation is still low. The mutation must occur at the right base $(P=1 / 6)$, and it must substitute the correct new base at that point $(P=$ $1 / 3)$. Thus, the probability associated with the random gain of a given restriction site under these conditions is $1 / 18$. By contrast, any single mutation in a given hexameric restriction site always $(P=1)$ leads to an alteration of its sequence and to the loss of that site. These probabilities do not take

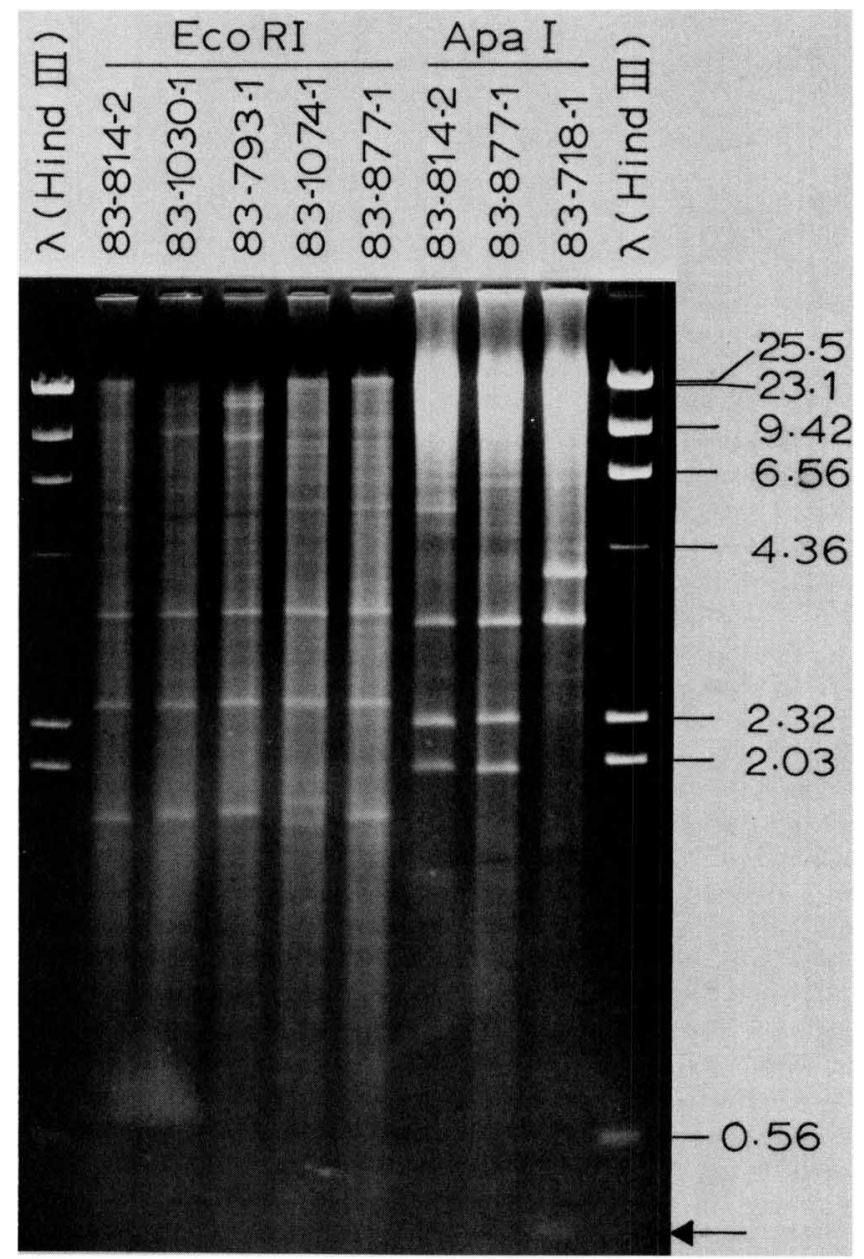

FIG. 1. Photograph of a $1.5 \%$ agarose gel showing various patterns of EcoRI and ApaI fragments. The sizes (in kilobases) of the fragments of a $\lambda$ HindIII digest are shown on the right. The arrow indicates the position of the smaller $(0.40-\mathrm{kb})$ ApaI fragment of strain UWO(PS) 83-718-1. 


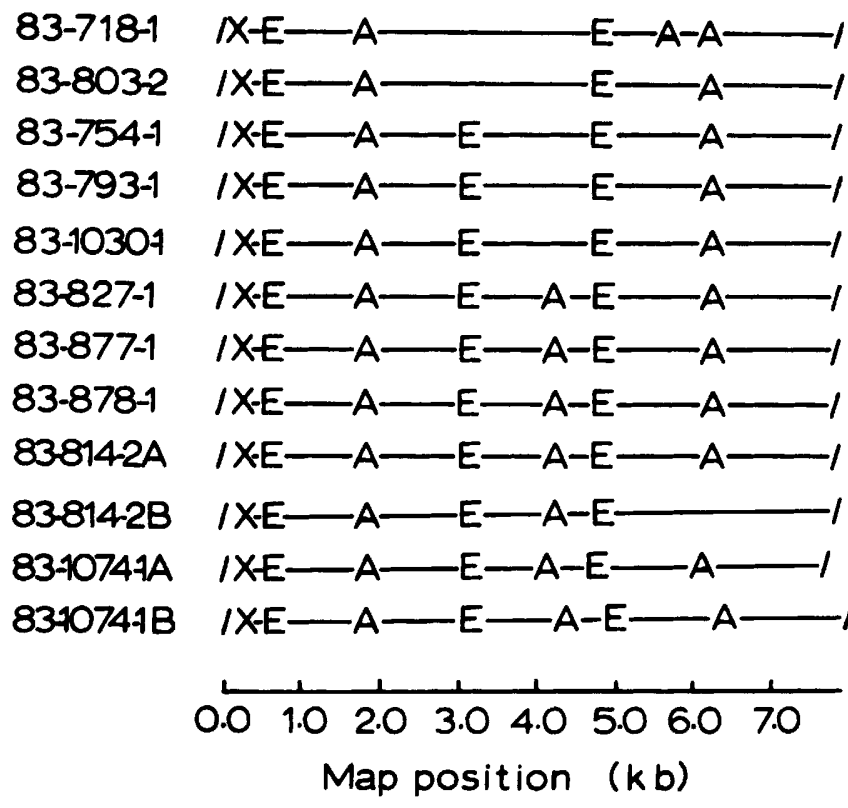

FIG. 2. Restriction maps of tandemly repeated DNAs of Clavispora sp. strains.

into account specific mutation rates at the sites, and it must be assumed that certain selective pressures may act upon the DNA sequences. Nonetheless, the independent appearance of the same restriction site at the same position in several individuals remains very unlikely $\left(P<18^{-n}\right.$ for $n$ individuals), regardless of what selective pressures are in effect. Consequently, one may generally attribute to the two possible states (present or absent) of these sites a directionality in time (polarity). The frequent presence of a restriction site at a given location in several maps must be regarded as ancestral, and the loss of any of these sites must be considered derived. The four identical maps proposed for strains UWO(PS) 83-827-1, UWO(PS) 83-877-1, UWO(PS) 83-878-1, and UWO(PS) $83-814-2$ in Fig. 2 possess all possible ApaI and $E c o$ RI sites except one (the $A p a I$ site at $5.5 \mathrm{~kb}$ ), and thus these maps are probably ancestral.

The hypothetical scheme proposed in Fig. 3 is based on the considerations described above. The restriction map found most often in the Clavispora sp. strains may have given rise, through the loss of the Apal site at $5.9 \mathrm{~kb}$, to the second map deduced for strain UWO(PS) 83-814-2 (designated 83-814-2B). The pair of maps obtained for strain UWO(PS) 83-1074-1 may be explained by the deletion of ca. 70 base pairs between positions 3.0 and 4.0 of one repeat unit similar to the ancestral map, concomitant with their insertion into another copy at the same position. The result would be the generation of two new repeat units differing from one another by about 140 base pairs. Prolonged electrophoresis of an XhoI digest of strain UWO(PS) 83-1074-1 on $0.5 \%$ agarose did not show this. The detection of such a small difference $(1.8 \%)$ by agarose electrophoresis may not be possible, and the mobility differences observed in smaller fragments may have been due to base composition differences. Therefore, the true nature of the heterogeneity identified in this strain remains unclear, and the model presented here must be considered provisional. The loss of the ApaI site at $4.0 \mathrm{~kb}$ from the ancestal map could have given rise to the maps shown for strains UWO(PS) 83-754-1, UWO(PS) 83-793-1, and UWO(PS) 83-1030-1. The additional loss of the
EcoRI site at $3.0 \mathrm{~kb}$ could account for the map of strain UWO(PS) 83-803-2, and the subsequent gain of a new ApaI site at $5.5 \mathrm{~kb}$ could yield the map of strain UWO(PS) 83-718-1 shown. The latter change is the only one where the acquisition of a new site must be invoked. In view of the double loss required to generate the map of strain UWO(PS) 83-803-2, the addition of the ApaI site at $5.5 \mathrm{~kb}$ is the most parsimonious supposition.

Larger fragments. Every strain yielded a number of large EcoRI repeated fragments (Table 3), which were particularly evident in strains UWO(PS) 83-1030-1 and UWO(PS) 83-793-1 (Fig. 1). Comparable fragments were not detected after digestion with the other nucleases, although some could have been obscured by unique DNA fragments present in some digests. The mobilities of the large EcoRI fragments were not affected by digestion with the other nucleases (data not shown). Although there is no reason to think that these large fragments (Table 3) are associated with the smaller ones (Table 2), their respective distributions among strains are not totally uncorrelated. For example, strain UWO(PS) 83-718-1 exhibited a unique 29-kb EcoRI fragment, and it was also distinguished from other strains by virtue of its unique 4.0- and 0.40-kb ApaI fragments. Strains UWO(PS) 83-754-1 and UWO(PS) 83-793-1 both possessed three large EcoRI fragments $(8.6,12$, and $15 \mathrm{~kb})$, a similarity reflected in their smaller fragments.

Ecological significance. Figures 2 and 3 provide a means of assessing degrees of variation among strains which are otherwise practically indistinguishable (Lachance, unpublished data). Strains UWO(PS) 83-718-1 and UWO(PS) 83-803-2 were the most distinct. The former strain was recovered from a columnar cactus (Table 1), whereas all other strains were isolated from prickly pear fruits or associated Drosophila spp., the more usual habitats of " $C$. opuntiae" (8). The divergence observed at the molecular level may be associated with a shift to a new habitat. Strain UWO(PS) 83-803-2 was unusual only in that it was the sole representative of mating type $h_{2}$ among the six strains from Great Inagua in the southern Bahamas (Table 1). The significance of this is not clear. Other mating type $h_{2}$ strains were recovered on Navassa Island (southwest of Haiti) and were not particularly striking in their DNA patterns. The similarity between strain UWO(PS) 83-1030-1 and other strains was surprising in view of the recovery of strain UWO(PS) 83-1030-1 from a separate locality. This strain differed from

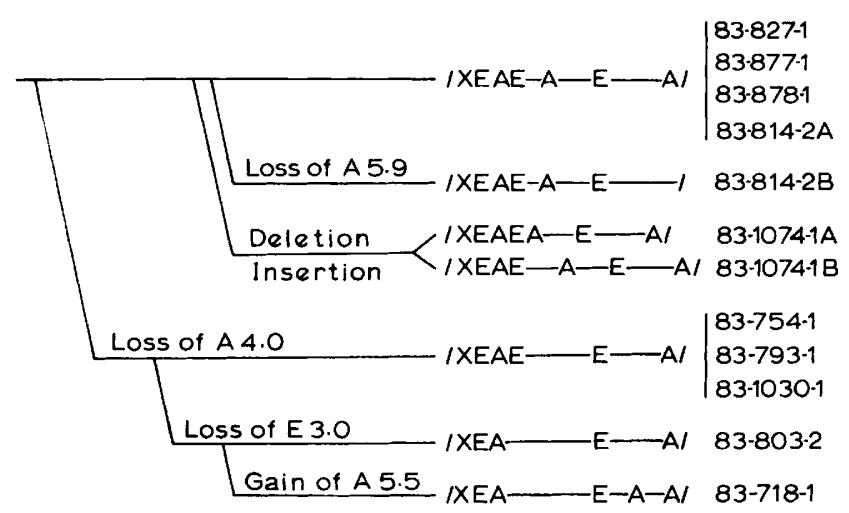

FIG. 3. Hypothetical filiation among restriction maps of tandemly repeated DNAs of Clavispora sp. strains. The abbreviated maps are not to scale. A 5.9, A 4.0, and A 5.5, ApaI sites at 5.9, 4.0, and $5.5 \mathrm{~kb}$, respectively; E 3.0, EcoRI site at $3.0 \mathrm{~kb}$. 
strains UWO(PS) 83-754-1 and UWO(PS) 83-793-1 only in its larger repeated fragments.

Evolutionary significance. It is important to realize that the diagram presented in Fig. 3 is an attempt to retrace the evolutionary history of the tandem repeats themselves and does not constitute an absolute reflection of the phylogeny of the yeast strains. This is especially true for this particular yeast species, which, unlike many other yeasts, is a sexual outbreeder. A certain amount of reticulate evolution is expected in organisms which collectively participate to some degree in the edification of a gene pool. Widespread mating probably does not occur because this yeast, like other yeasts, propagates asexually as well. Obligate sexuality should result in a greater frequency of heterogeneous strains. Our finding of heterogeneity in only 2 of 10 strains may be a result of this, but it is also affected by the fact that the detection of heterogeneity is only possible when the "second version" of the tandem repeat is present in a high enough proportion to be visible on a stained electrophoretic gel. The actual frequency of heterogeneity is probably higher.

Taxonomic significance. Although the present study was restricted to conspecific strains, we have shown that variation among repeated DNAs in a single species is not excessive. Preliminary investigations involving several strains of Clavispora lusitaniae (Lachance and Olson, unpublished data) revealed the presence of 3.4-kb EcoRI and 3.3-kb ApaI fragments very similar to those described here. This indicates that the conserved region surrounding the $\mathrm{XhoI}$ site is present in both species. The repeat unit in $C$. lusitaniae is about $9 \mathrm{~kb}$ long, and the variable region in it is more complex. It contains one or more XhoI sites, and its mapping may require extraction and restriction of purified fragments. The sizes of the fragments obtained from Saccharomyces cerevisiae also add up to $\mathrm{ca} .9 \mathrm{~kb}$. These fragments are devoid of Xhol sites and appear to be more complex.

Nature of tandem repeated DNA in Clavispora sp. The 7.6-kb repeated DNA of Clavispora sp. accounts for approximately $7.4 \%\left(\sigma^{2}=1.5\right)$ of the total DNA, as estimated by densitometry of various restriction digests. Assuming a genome size on the order of $10^{7} \mathrm{~kb}$ (not determined), the sequences are repeated approximately 100 times per genome. Their function is unknown.

Tandemly repeated DNA in other yeasts. Repetitive DNAs of varying sizes are widespread in yeasts and many other eucaryotes. Repeat units comparable in size $(9.1 \mathrm{~kb})$ to those found in Clavispora are detectable in Saccharomyces by subjecting total yeast DNA to digestion with one of several restriction endonucleases (e.g., EcoRI) and to electrophoresis of the products on an agarose gel (1). They are found at a rate of 100 to 140 copies per haploid genome, and they represent between 7 and $20 \%$ of the total DNA. Hybridization with rRNA has shown that these repeat units carry a collection of genes coding for $25 \mathrm{~S}, 18 \mathrm{~S}, 5.8 \mathrm{~S}$, and $5 \mathrm{~S}$ rRNAs, plus spacer sequences. Accordingly, they have been termed ribosomal DNA (rDNA). Spacer portions of rDNA are variable enough to reveal differences between Saccharomyces cerevisiae and Saccharomyces carlsbergensis (9), whereas the ribonucleic acid coding regions are sufficiently conserved to allow meaningful comparisons between yeasts and Drosophila by sequencing (6). Considerable homology and some degrees of variability have been observed among rDNAs of Saccharomyces species and of Torulaspora delbrueckii (synonym, Saccharomyces rosei), Pichia canadensis (synonym, Hansenula wingei), and
Kluyveromyces lactis (10). Schizosaccharomyces pombe rDNAs are quite different from those of the other yeasts studied, especially in that their sequences coding for $5 \mathrm{~S}$ rRNA are located separately from other rDNAs (1). The rDNA sequences identified in the above yeast species range in size from 8.5 to $11.1 \mathrm{~kb}(1,10)$, but the sizes of the rRNA cistrons themselves add up to ca. $5 \mathrm{~kb}$.

Conclusions. The characterization of tandemly repeated yeast DNA by restriction mapping is methodologically accessible for taxonomic and related purposes. This approach holds some promise in a biogeographic perspective if larger samples of strains are examined. The data are amenable to analysis by a simple diagramatic approach and also should lend themselves to numerical phenetic examination. The applicability of repetitive DNA mapping to intraspecific comparisons in Clavispora sp. is evident, although the full significance of the variation remains to be explored. The conserved nature of part of the repetitive DNA allows an optimistic outlook on the possible use of mapping to compare different yeast species. The applicability of this method to intergeneric comparisons is uncertain at this time.

\section{ACKNOWLEDGMENTS}

This project was sponsored by the Natural Science and Engineering Research Council of Canada through an operating grant to M.-A.L. and summer research scholarships to A.L. and D.L.P. The collection of yeast strains was made possible through National Science Foundation grant DEB 8108679 to W. T. Starmer.

Jane Bowles and lan Craig deserve special gratitude for helping to assemble gel photographic equipment. We thank Carol Rees for sharing her knowledge and excitement.

\section{LITERATURE CITED}

1. Bicknell, J. N., and H. C. Douglas. 1970. Nucleic acid homologies among species of Saccharomyces. J. Bacteriol. 101:505-512.

2. Bollon, A. P. 1983. Organization of fungal ribosomal RNA genes, p. 67-125. In H. Busch and L. Rothblum (ed.), The cell nucleus, vol. 10. rDNA, part A. Academic Press, Inc., New York.

3. Cryer, D. R., R. Eccleshall, and J. Marmur. 1975. Isolation of yeast DNA. Methods Cell Biol. 12:39-44.

4. Kurtzman, C. P., H. J. Phaff, and S. A. Meyer. 1983. Nucleic acid relatedness among yeasts, p. 139-166. In J. F. T. Spencer, D. M. Spencer, and A. R. W. Spencer (ed.), Yeast genetics, fundamental and applied aspects. Springer-Verlag, New York.

5. Maniatis, T., E. F. Fritsch, and J. Sambrook. 1982. Molecular cloning, a laboratory manual. Cold Spring Harbor Laboratory, Cold Spring Harbor, N.Y.

6. Mao, J., B. Appel, J. Schaack, S. Sharp, H. Yamada, and D. Soll. 1982. The SS RNA genes of Schizosaccharomyces pombe. Nucleic Acids Res. 10:487-500.

7. Phaff, H. J. 1984. General classification of the yeasts. III. DNA, enzymes and cell wall, p. 17-21. In N. J. W. Kreger-van Rij (ed), The yeasts, a taxonomic study. Elsevier/North-Holland Publishing Co., Amsterdam.

8. Starmer, W. T., and H. J. Phaff. 1983. Analysis of the community structure of yeasts associated with the decaying stems of cactus. II. Opuntia species. Microb. Ecol. 9:247-259.

9. Veldman, G. M., J. Klootwijk, P. DeJonge, R. J. Leer, and R. J. Planta. 1980. The transcription termination site of the ribosomal RNA operon in yeast. Nucleic Acids Res. 8:5179-5192.

10. Verbeet, M. P., H. van Heerikhuizen, J. Klootwijk, R. D. Fontijn, and R. J. Planta. 1984. Evolution of yeast ribosomal DNA: molecular cloning of the rDNA units of Kluyveromyces lactis and Hansenula wingei and their comparison with the rDNA units of other Saccharomycetoideae. Mol. Gen. Genet. 195:116-125. 